\title{
Making Simple Repairs: Repairing Screens ${ }^{1}$
}

\section{Mary N. Harrison ${ }^{2}$}

Holes in your screens allow insects, including flies, mosquitoes, and cockroaches to enter your home. This problem is easy to fix.

\section{Supplies Needed:}

- Screen wire or ready-cut screen patches

- Scissors

- A ruler or small box with a straight edge

\section{How To Fix}

Repair: Trim the hole in the screen to make smooth edges. (Figure 1)

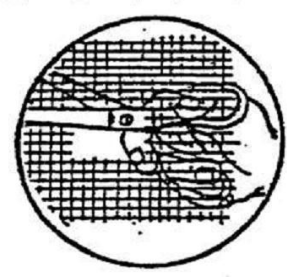

Figure 1.
Cut a rectangular patch an inch larger, on each side, than the hole. Remove the three outside wires on each of the four sides of the patch. (Figure 2)

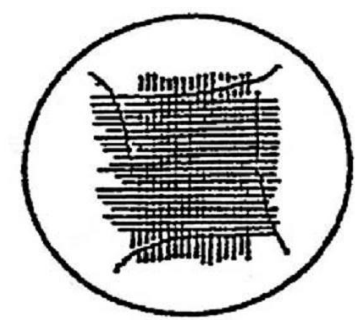

Figure 2.

Bend the ends of the wires over the box or the edge of a ruler. (Figure 3)

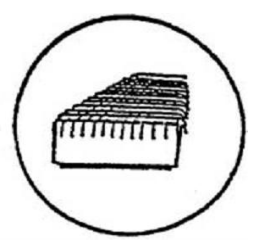

Figure 3.

1. This document is FCS5234-09, one of a series of the Department of Family, Youth and Community Sciences, Florida Cooperative Extension Service, Institute of Food and Agriculture Sciences, University of Florida. Publication: May 2002. Revised: December 2005. Please visit the EDIS Web site at http://edis.ifas.ufl.edu.

2. Mary N. Harrison, professor, Department of Family, Youth and Community Sciences, Cooperative Extension Service, Institute of Food and Agricultural Sciences, University of Florida, Gainesville, 32611.

The Institute of Food and Agricultural Sciences (IFAS) is an Equal Opportunity Institution authorized to provide research, educational information and other services only to individuals and institutions that function with non-discrimination with respect to race, creed, color, religion, age, disability, sex, sexual orientation, marital status, national origin, political opinions or affiliations. U.S. Department of Agriculture, Cooperative Extension Service, University of Florida, IFAS, Florida A. \& M. University Cooperative Extension Program, and Boards of County Commissioners Cooperating. Larry Arrington, Dean 
On the outside of the screen put the patch over the hole. Hold the patch tight against the screen so that the small wire ends go through the screen.

(Figure 4)

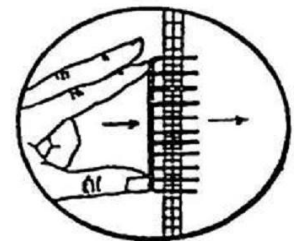

Figure 4.

On the inside of the screen, bend down the ends of the wires toward the middle of the hole. You may have someone on the outside of the screen to press against the patch while you bend the wire ends.

(Figure 5)

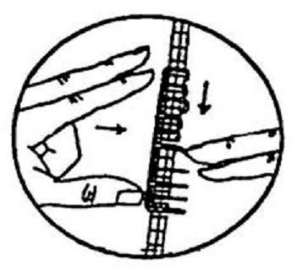

Figure 5.

Now your screen is patched. The hole is covered.

Another way to mend a very small hole is to use a needle and thread. Match the color of the thread to the color of the screen. Sew back and forth to fill in the hole.

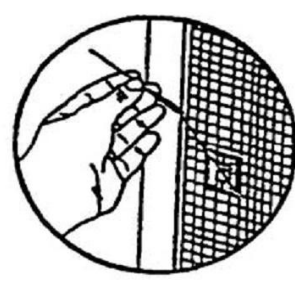

Figure 6. 